\title{
EVALUATION OF THE EFFECTS OF OZONE THERAPY IN THE TREATMENT OF INTRA-ABDOMINAL INFECTION IN RATS
}

\author{
Yglesio Moyses de Souza, ${ }^{\text {I Belchor Fontes, }}$, Joilson O Martins, ${ }^{\text {II }}$ Paulina \\ Sannomiya, ${ }^{\text {III }}$ Glacus S. Brito, ${ }^{\mathrm{I}}$ Riad N. Younes, ${ }^{\mathrm{I}}$ Samir Rasslan ${ }^{\mathrm{I}}$ \\ doi: $10.1590 / \mathbf{S 1 8 0 7 - 5 9 3 2 2 0 1 0 0 0 0 2 0 0 0 1 2}$
}

de Souza YM, Fontes B, Martins JO, SannomiyaP, Brito GS, Younes RN, Rasslan S. Evaluation of the effects of ozone therapy in the treatment of intra-abdominal infection in rats. Clinics. 2010;65(2):195-202.

INTRODUCTION: The antibacterial effect of ozone $\left(\mathrm{O}_{3}\right)$ has been described in the extant literature, but the role of $\mathrm{O}_{3}$ therapy in the treatment of certain types of infection remains controversial.

OBJECTIVES: To evaluate the effect of intraperitoneal (i.p.) $\mathrm{O}_{3}$ application in a cecal ligation/puncture rat model on interleukins (IL-6, IL-10) and cytokine-induced neutrophil chemoattractant (CINC)-1 serum levels, acute lung injury and survival rates.

METHODS: Four animal groups were used for the study: a) the SHAM group underwent laparotomy; b) the cecal ligation/puncture group underwent cecal ligation/puncture procedures; and c) the $\mathrm{CLP}+\mathrm{O}_{2}$ and $\mathrm{CLP}+\mathrm{O}_{3}$ groups underwent CLP+ corresponding gas mixture infusions (i.p.) throughout the observation period. IL-6, CINC-1 and IL-10 concentrations were determined by enzymelinked immunosorbent assay (ELISA). Acute lung injury was evaluated with the Evans blue dye lung leakage method and by lung histology. $P<0.05$ was considered significant.

RESULTS: CINC-1 was at the lowest level in the SHAM group and was lower for the CLP+O $\mathrm{O}_{3}$ group vs. the CLP+O $\mathrm{O}_{2}$ group and the cecal ligation/puncture group. IL-10 was lower for the SHAM group $v s$. the other three groups, which were similar compared to each other. IL-6 was lower for the SHAM group vs. all other groups, was lower for the $\mathrm{CLP}+\mathrm{O}_{3}$ or $\mathrm{CLP}+\mathrm{O}_{2}$ group vs. the cecal ligation/puncture group, and was similar for the $\mathrm{CLP}+\mathrm{O}_{3}$ group vs. the $\mathrm{CLP}+\mathrm{O}_{2}$ group. The lung histology score was lower for the SHAM group $v s$. the other groups. The Evans blue dye result was lower for the $\mathrm{CLP}+\mathrm{O}_{3}$ group $v s$. the $\mathrm{CLP}+\mathrm{O}_{2}$ group and the cecal ligation/puncture group but similar to that of the SHAM group. The survival rate for the $\mathrm{CLP}+\mathrm{O}_{3}$ group was lower than for the SHAM group and similar to that for the other 2 groups (CLP and CLP+O ${ }_{2}$ ).

CONCLUSION: Ozone therapy modulated the inflammatory response and acute lung injury in the cecal ligation/puncture infection model in rats, although there was no improvement on survival rates.

KEYWORDS: IL-6; IL-10; CINC-1; Sepsis; ALI; CLP.

\section{INTRODUCTION}

Despite the latest advances in antimicrobial therapy and intensive care, peritonitis and sepsis remain important causes of mortality. Infectious peritonitis can be due to intestinal

\footnotetext{
${ }^{\text {I }}$ Faculdade de Medicina da Universidade de São Paulo - São Paulo/SP, Brazil II Department of Immunology, Institute of Biomedical Sciences, Faculdade de Medicina da Universidade de São Paulo - São Paulo/SP, Brazil

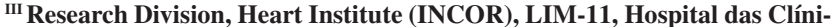
cas da Faculdade de Medicina da Universidade de São Paulo - São Paulo/ SP, Brazil

Email:yglesio@yahoo.com

Tel.: 55113061.7216

Received for publication on September 14, 2009

Accepted for publication on November 04, 2009
}

perforation resulting from various conditions, including trauma, inflammatory diseases, ischemia and perforated neoplasms. ${ }^{1}$ Local infection triggers a massive release of interleukin (IL)-1 $\beta$, tumor necrosis factor (TNF)- $\alpha$, IL-10, platelet activating factor (PAF), leukotrienes, and thromboxane, all of which participate in the development of sepsis syndrome and septic shock. ${ }^{2,3}$

After initiation of the infection process, regardless of the optimal treatment, the inflammatory cascade is sometimes irreversible and results in patient death. Extensive research has focused on elucidating the mechanisms of the inflammatory cascade and modulation of these responses to prevent and treat Systemic Inflammatory Response 
Syndrome (SIRS) and Multiple Organ Dysfunction Syndrome (MODS) $)^{4,5}$.

Ozone $\left(\mathrm{O}_{3}\right)$ is a potent oxidizing agent and an important disinfectant. The bactericidal effect of $\mathrm{O}_{3}$ is based on a direct attack on microorganisms by oxidation of biological materials. In fact, $\mathrm{O}_{3}$ antibacterial activity can be more effective than iodine and chlorine. ${ }^{6,7}$ Data reported in the literature have shown that bacteria, spores, and viruses are inactivated by ozone after only few minutes of exposure ${ }^{8,9}$. $\mathrm{O}_{3}$ may act through mechanisms other than oxidation, including the activation of erythrocyte metabolism and immune cells. ${ }^{10,11}$

Toxic effects of $\mathrm{O}_{3}$, caused by excessive doses of inhaled ozone in the airways, as well as toxicity to the endocrine, reproductive, and central nervous systems have been described ${ }^{7,12}$. Nevertheless, little is known about the intraperitoneal (i.p.) application of ozone or the repercussions that ozone has on intra-abdominal organs and tissues.

Two studies ${ }^{13,14}$ tested a preconditioning $\mathrm{O}_{2} / \mathrm{O}_{3}$ pneumoperitoneum in rats submitted to peritonitis. The former study ${ }^{13}$ added an antibiotic regimen to the preconditioning pneumoperitoneum, and both found an increased survival rate in rats after the treatments. However, another study ${ }^{15}$ that evaluated preconditioning $\mathrm{O}_{2} / \mathrm{O}_{3}$ pneumoperitoneum demonstrated a pro-inflammatory effect of $\mathrm{O}_{3}$, with a tendency to reduce survival rates.

In this context, beyond these controversial results, the real effects of ozone therapy as a single therapeutic agent, not as a preconditioning treatment or as an adjuvant to antibiotics, have not been clearly determined. Thus, the objective of this study was to evaluate the effect of i.p. $\mathrm{O}_{3}$ application in a cecum ligation/puncture (CLP) rat model on the markers of the inflammatory response, on acute lung injury (ALI) parameters (pulmonary vascular permeability and histology), and on an animal's survival rate.

\section{MATERIALS AND METHODS}

This study was performed in the Laboratory of Medical Investigation (LIM)-62 of the third Division of Surgical Clinic of the Hospital das Clinicas and the LIM 11 University of São Paulo Medical School. Wistar male rats (250-350 g) were utilized throughout the experiments. This study was approved by our Institutional Ethics Committee and performed according to the National Institutes of Health (NIH) guidelines on the experimental use of animals. ${ }^{16}$

Four groups of rats were employed in this study:

1) SHAM group animals were submitted only to laparotomy (hereafter this group is referred to as "group SHAM");

2) CLP group animals were submitted to laparotomy + CLP procedures (hereafter this group is referred to as "group CLP");

3) $\mathrm{CLP}+\mathrm{O}_{2}$ group animals were submitted to laparotomy + $\mathrm{CLP}+\mathrm{O}_{2}$ treatment (hereafter this group is referred to as "group CLP+O ${ }_{2}$ ");

4) $\mathrm{CLP}+\mathrm{O}_{3}$ group animals were submitted to laparotomy + $\mathrm{CLP}+\mathrm{O}_{3} / \mathrm{O}_{2}$ treatment (hereafter this group is referred to as "group $\mathrm{CLP}+\mathrm{O}_{3}$ ").

The lengths of the observation periods varied and are specified in the respective descriptive topics in this Methods section. The study design and distribution of the animals are shown in Figure 1. All of the animals fasted for $8 \mathrm{~h}$ before the surgical procedure. Laparotomy and cecal ligation/ puncture were performed under general anesthesia with inhalatory halothane, followed by i.p. pentobarbital injection $(50 \mathrm{mg} / \mathrm{kg}) \cdot{ }^{17-19}$

During the procedures, the animals were randomized to the 4 groups immediately after cecum exposure was accomplished. The SHAM rats were submitted to a $2-\mathrm{cm}$ laparotomy, followed by exposure of the cecum and closure of the abdominal wall incision with a 4.0 nylon 2-layer running suture.

\section{Cecum ligation and puncture and treatment with $\mathrm{O}_{2}$ or $\mathrm{O}_{2} / \mathrm{O}_{3}$}

After a 2-cm laparotomy on groups CLP, CLP+O ${ }_{2}$, and $\mathrm{CLP}+\mathrm{O}_{3}$, the cecum was exposed, ligated with a 3.0 silk suture just distal to the ileocecal valve to avoid intestinal obstruction, and punctured once with a $22 \mathrm{~g}$ needle in its antimesenteric border. The cecum was then squeezed to expel a small amount of fecal material through the puncture site. The bowel was returned to the abdominal cavity, and the abdominal wall incision was closed, as described for group SHAM. The animals were kept warm $\left(37^{\circ} \mathrm{C}\right)$ in the postoperative period. Food and water (with dipyrone $0.5 \%$ ) were offered ad libitum after this procedure. ${ }^{18,20}$ For the treatment with $\mathrm{O}_{2}$ or $\mathrm{O}_{2} / \mathrm{O}_{3}$, the animals were anesthetized with halothane before the injection procedure. On group $\mathrm{CLP}+\mathrm{O}_{2}, 100 \% \mathrm{O}_{2}(20 \mathrm{ml} / \mathrm{kg})$ was insufflated (i.p.) every $12 \mathrm{~h}$ through a puncture in the right lower abdomen with a 22 gauge needle, starting 1 hour after the laparotomy closure. Similarly, group $\mathrm{CLP}+\mathrm{O}_{3}$ received a gas mixture $(20 \mathrm{ml} / \mathrm{kg}$, i.p.) containing $5 \%$ ozone $(102 \mu \mathrm{g} / \mathrm{mL})$ and $95 \%$ oxygen, generated by a $\mathrm{MVM}^{\mathrm{TM}}$ ozone generator (Multivácuo ${ }^{\circledast}$, Campinas, Brazil), every 12 h, starting 1 hour after laparotomy closure. After recovery from anesthesia recovery, the animals were allowed to have food and water (with dipyrone $0.5 \%$ ) ad libitum during the observation period. 


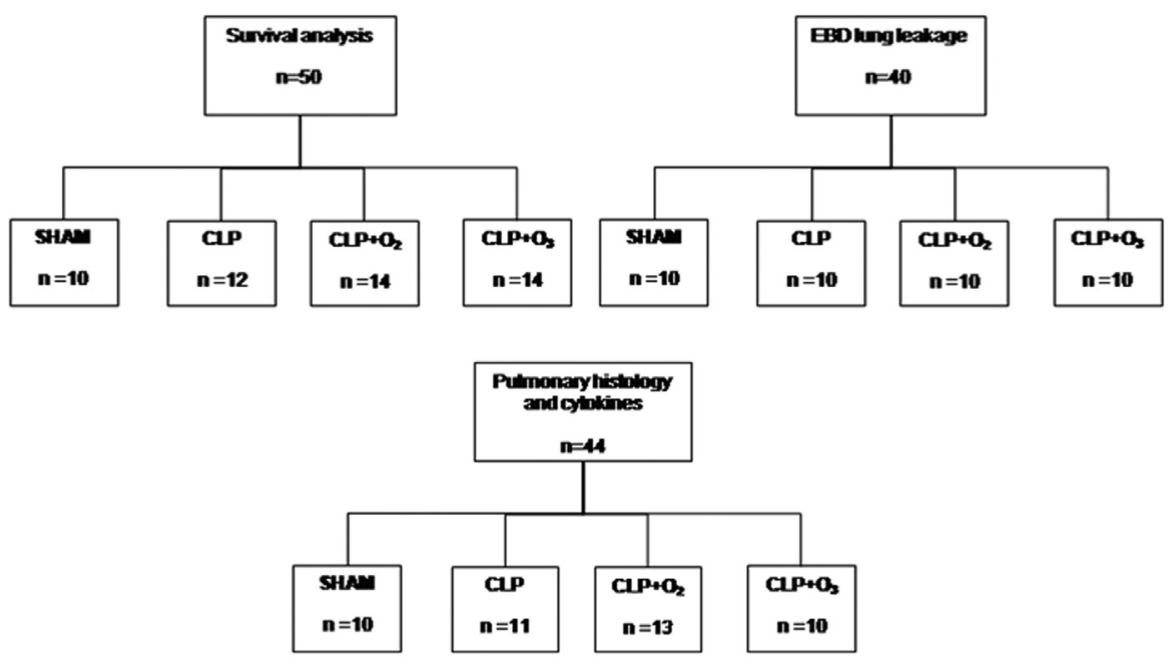

Figure 1 - Study design. The animals were assigned to 4 groups: 1) SHAM, animals submitted to laparotomy and exposure of the cecum; 2) CLP, animals underwent cecal ligation/puncture and were observed; 3) $\mathrm{CLP}+\mathrm{O}_{2}$, animals submitted to cecal ligation/puncture and were treated i.p. with $\mathrm{O}_{2}$; and 4) $\mathrm{CLP}+\mathrm{O}_{3}$, animals submitted to cecal ligation/puncture and were treated i.p. with $\mathrm{O}_{3}$. For the survival analysis, $\mathrm{n}=40\left(\mathrm{SHAM}=10, \mathrm{CLP}=12, \mathrm{CLP}+\mathrm{O}_{2}=14\right.$, $\mathrm{CLP}+\mathrm{O}_{3}=14$ ). Pulmonary vascular permeability was evaluated by the EBD lung leakage method in 40 animals (all groups with $\mathrm{n}=10$ ). Cytokine sampling and histological analysis were studied in 44 animals ( $\left.\mathrm{SHAM}=10, \mathrm{CLP}=11, \mathrm{CLP}+\mathrm{O}_{2}=13, \mathrm{CLP}+\mathrm{O}_{3}=10\right)$.

\section{Enzyme-immuno assays for cytokines and chemokine}

Serum levels of the markers of the inflammatory response as well as the pulmonary histology changes were simultaneously evaluated in 44 animals (SHAM=10, $\left.\mathrm{CLP}=11, \mathrm{CLP}+\mathrm{O}_{2}=13, \mathrm{CLP}+\mathrm{O}_{3}=10\right)$.

The serum concentrations of cytokines and chemokines (IL-6, IL-10 and CINC-1) were determined by enzymeimmuno assay (ELISA) using commercially available kits, according to the manufacturer's instructions (R \& D Systems Inc., Minneapolis, MN, USA). The sensitivity of the assay was $15 \mathrm{pg} / \mathrm{mL} .^{21}$

\section{Pulmonary Histology}

Twenty-four $\mathrm{h}$ after the initial procedure (laparotomy for group SHAM or CLP for the other groups), all of the animals were anesthetized with an injection of sodium pentobarbital $(50 \mathrm{mg} / \mathrm{kg}$, i.p.). A median sternotomy provided access to the thoracic cavity, and $5 \mathrm{ml}$ of blood was collected from an intracardiac punction (22 gauge needle). This sample was used for cytokines and chemokine analysis. Euthanasia was then performed by cutting the left ventricle with scissors. A piece of the lower lobe of the left lung was fixed in $4 \%$ formaldehydum polymerisatum. Paraffinembedded sections $(5 \mu \mathrm{m})$ were stained with hematoxylineosin and submitted to morphological analysis, including extension (EX) of pulmonary involvement, edema (ED), hemorrhage $(\mathrm{H})$, congestion $(\mathrm{C})$, polymorphonuclear $(\mathrm{PO})$ cell infiltrate and mononuclear (MO) cell infiltrate. A semi- quantitative analysis was performed, due to heterogeneous morphological changes and pulmonary involvement. A score (S) was calculated that combined the extension of pulmonary involvement and intensity of each morphological change, resulting in a final score $[\mathrm{S}=\mathrm{EX} \times(\mathrm{ED}+\mathrm{H}+\mathrm{C}+\mathrm{PO}+\mathrm{MO})]^{22}$. Two different pathologists conducted a blind histological analysis.

\section{Pulmonary vascular permeability evaluation}

Acute lung injury was determined in 40 animals $\left(\mathrm{SHAM}=10, \mathrm{CLP}=10, \mathrm{CLP}+\mathrm{O}_{2}=10, \mathrm{CLP}+\mathrm{O}_{3}=10\right)$ by evaluating the lung vascular permeability with the Evans blue dye (EBD) lung leakage method. Twenty-four $\mathrm{h}$ after the initial procedure (laparotomy for group SHAM or CLP in the other groups), the animals were anesthetized with an injection of sodium pentobarbital $(50 \mathrm{mg} / \mathrm{kg}$, i.p. $)$, followed by the injection of $20 \mathrm{mg} / \mathrm{kg}$ EBD (delivered at a concentration of $25 \mathrm{mg} / \mathrm{ml} \mathrm{EBD}$ in water,intravenous- (i.v.).

Fifteen minutes after the initial procedure, the laparotomy incision was reopened in all of the animals. Euthanasia was conducted by cutting the inferior vena cava. The thoracic cavity was then opened, and the lungs were perfused for $3 \mathrm{~min}$ with $50 \mathrm{ml}$ phosphate-buffered saline (PBS) (pH 7.4) injected through a cannula inserted into the pulmonary artery. After dissection and en block removal of the heart and lungs, the left lung lobe was divided into two samples that were weighed to obtain the wet weight (WW) of each specimen. One sample was held in an oven at $100^{\circ} \mathrm{C}$ for $24 \mathrm{~h}$ and then weighed to determine its dry weight (DW). 
The dry to wet weight ratio (\% DW/WW) of the lung tissue was then calculated. The other sample was submersed in formamide ( $4 \mathrm{ml}$ formamide/g wet tissue) for $24 \mathrm{~h}$ to extract the dye from the tissue. The dye absorbance value in the solution was then detected by a microplate reader (wave length, $620 \mathrm{~nm}$ ), compared with a series of standard EBD dilutions in formamide, and converted to $\mu \mathrm{g}$ of $\mathrm{EBD} / \mathrm{mL}$ of the solution. Based on this value, the amount of EBD that had been in the wet lung sample ( $\mu \mathrm{g} \mathrm{EBD} / \mathrm{g}$ wet tissue) was then determined. Finally, the $\% \mathrm{DW} / \mathrm{WW}$ was used to convert the wet tissue value into a $\mu \mathrm{g} \mathrm{EBD} / \mathrm{g}$ dry lung tissue value, which was recorded as the EBD lung leakage value. ${ }^{23,24}$

\section{Survival analysis}

For survival rate determination, the animals were observed until the $5^{\text {th }}$ day post procedure. The survival rates were analyzed in 50 animals (SHAM $=10, C L P=12$, $\mathrm{CLP}+\mathrm{O}_{2}=14, \mathrm{CLP}+\mathrm{O}_{3}=14$ ), and all of the groups were observed for 5 days. The period of time from the initial procedure until death was annotated in h, and a Log-rank test was performed.

\section{Statistical Methods}

The Kolmogorov-Smirnov test was used to determine normality. The data are presented as the mean \pm SEM (when a normal distribution was found), or as the median (Md) plus the $25^{\text {th }}$ and $75^{\text {th }}$ percentiles $[\mathrm{Md}(\mathrm{P} 25 ; \mathrm{P} 75)]$ when the normality test failed. The parametric data were analyzed by ANOVA followed by the Bonferroni multiple comparisons test, when appropriate. The Kruskal-Wallis test was used to analyze the non-parametric data followed by the StudentNewman-Keuls test, when necessary. A Log-rank test was used for survival analysis. A $p$ value $<0.05$ was considered to be significant. Statistical analyses were conducted with Sigmastat ${ }^{\circledR}$ version 3.5 (Systat Software, Inc., Point Richmond, CA, USA).

\section{RESULTS}

\section{Cytokines and chemokine analysis}

The levels of CINC-1 and IL-10 were expressed as medians (P25; P75), and the level of IL-6 was expressed as the mean \pm SEM. CINC-1 levels $(\mathrm{pg} / \mathrm{mL})$ were significantly lower for group $\mathrm{CLP}+\mathrm{O}_{3}[951.3(582.6 ; 1111.5)]$ than for group CLP+O $2[1700(1300 ; 3928.1)]$ and group CLP [3555 (3066.8; 4404)]. Group SHAM had the lowest CINC-1 values $[47(43.2 ; 53.8)](p<0.01)$. The Kruskal-Wallis test, followed by the Student-Newman-Keuls test, found no

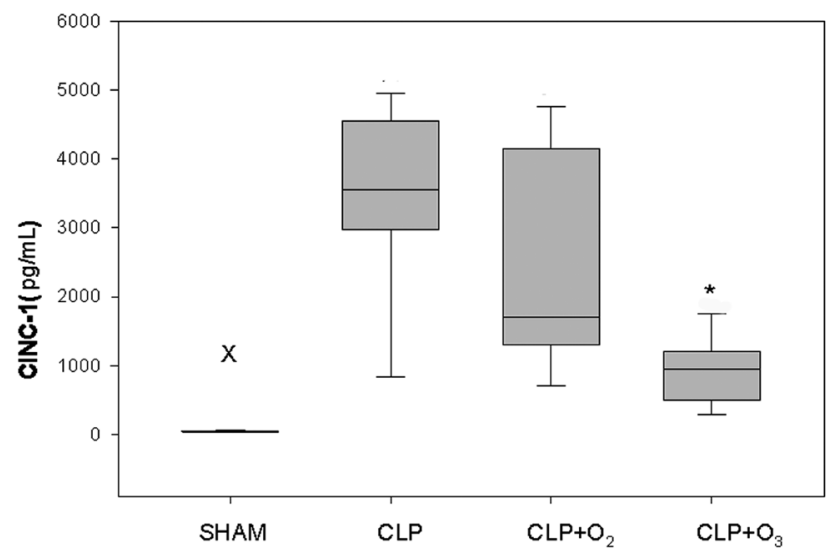

Figure 2 - Kruskal-Wallis test for CINC-1 levels $24 \mathrm{~h}$ after the initial procedure. SHAM animals had the lowest levels of all groups. Group $\mathrm{CLP}+\mathrm{O}_{3}$ had CINC-1 levels significantly lower than groups CLP and $\mathrm{CLP}+\mathrm{O}_{2}{ }^{3}$ Group SHAM $v s$. other groups $(P<0.01)$ * Group $\mathrm{CLP}+\mathrm{O}_{3} v s$. groups CLP and $\mathrm{CLP}+\mathrm{O}_{2}(P<0.05)$. Values of $\mathrm{CINC}-1$ are medians $(\mathrm{P} 25 ; \mathrm{P} 75)$ expressed in $\mathrm{pg} / \mathrm{mL}$.

significant difference between groups CLP and CLP $+\mathrm{O}_{2}$ (Figure 2).

IL-6 levels $(\mathrm{pg} / \mathrm{mL})$ were significantly lower for group SHAM $(30.8 \pm 4.8)$ than for all the other groups $(p<0.001)$. Groups $\mathrm{CLP}+\mathrm{O}_{3}(321.3 \pm 35.2)$ and $\mathrm{CLP}+\mathrm{O}_{2}(386.3 \pm 40.9)$ had lower levels than group CLP $(695 \pm 65.3)(p<0.01)$. A comparison between groups $\mathrm{CLP}+\mathrm{O}_{3}$ and $\mathrm{CLP}+\mathrm{O}_{2}$ showed no significant difference $(p=0.54)$.

IL-10 levels $(\mathrm{pg} / \mathrm{mL})$ for the four groups were 50.1 (38.8; 67) for group SHAM, $98.1(56.1 ; 598)$ for group CLP, 273.6 $(152 ; 314.8)$ for group $\mathrm{CLP}+\mathrm{O}_{2}$, and $199.5(107 ; 289)$ for group $\mathrm{CLP}+\mathrm{O}_{3}$. The Kruskal-Wallis test showed that IL-10 levels were lower for group SHAM $(p=0.02)$ than for the other groups. There was no difference between the other 3 groups $(p=0.85$ ) (Figure 3).

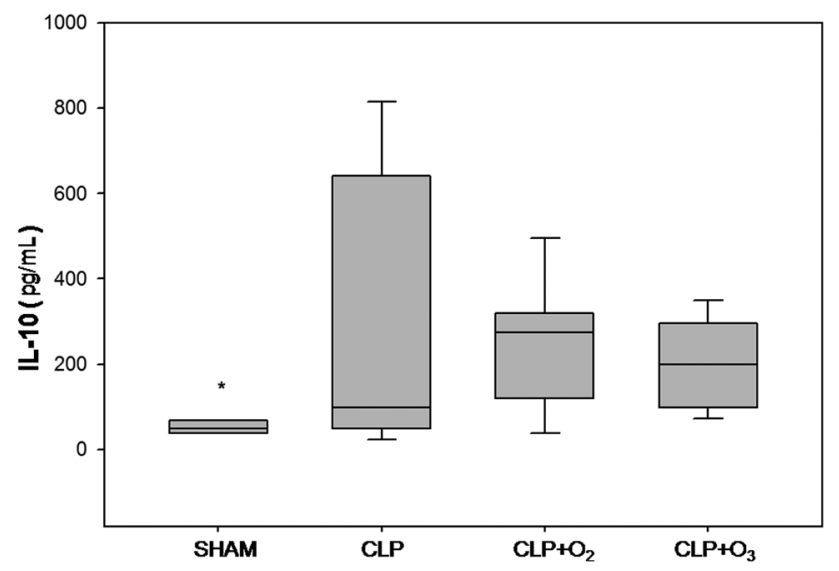

Figure 3 - Kruskal-Wallis test for IL-10 levels. The SHAM animals had lower levels of IL-10 than all other groups. There were no differences between groups CLP, $\mathrm{CLP}+\mathrm{O}_{2}$, and $\mathrm{CLP}+\mathrm{O}_{3}(p=0.855)$. The values are the median (P25; P75) expressed as pg/ml. * Group SHAM $v$ s. other groups $(P=0.02)$. 


\section{Pulmonary Histology}

For lung histology and cytokines analysis, we used 10 rats for group SHAM and, initially, 13 animals in each CLP procedure group. Two animals of group CLP and 3 animals of the group $\mathrm{CLP}+\mathrm{O}_{3}$ had an inadequate blood sample (hemolyzed plasma), so we eliminated these animals. SHAM rats had the lowest histology score $[3(2 ; 4)]$ of all groups $(p=0.002)$. The pulmonary histology scores were similar in groups $\mathrm{CLP}+\mathrm{O}_{2}[6(3.7 ; 10.5)], \mathrm{CLP}+\mathrm{O}_{3}[8(6 ; 8)]$, and CLP $[10(5 ; 12)]$. The Kruskal-Wallis test showed no differences between the three groups $(p=0.31)$.

\section{EBD lung leakage method}

The EBD lung leakage values were $62.5(39 ; 71.3)$ for group SHAM, $56.1(52.7 ; 109.1)$ for group CLP, 88.2 (53.6; 151.1) for group $\mathrm{CLP}+\mathrm{O}_{2}$ and $28.4(18.4 ; 51.3)$ for group $\mathrm{CLP}+\mathrm{O}_{3}$. There was a significant difference when we compared group $\mathrm{CLP}+\mathrm{O}_{3}$ with groups $\mathrm{CLP}+\mathrm{O}_{2}$ and CLP $(p=0.02)$. A comparison of groups $\mathrm{CLP}+\mathrm{O}_{3}$ and SHAM showed no significant difference.

\section{Survival Analysis}

For the survival analysis, we used 10 animals for group SHAM because of the low morbidity of the procedure. The groups with the CLP procedures initially had 14 animals, but 2 animals of group CLP died right after anesthesia and then were eliminated from the analysis.

Only one animal of group SHAM died during the observation period $(110 \pm 10 \mathrm{~h})$. All of the other groups had a decreased survival time compared to group SHAM $(p=0.002)$. The observed death rates were: $1 / 10(10 \%)$ for group SHAM, 9/12 (75\%) for group CLP, 6/14 (42.8\%) for group $\mathrm{CLP}+\mathrm{O}_{2}$, and 10/14 (71.4\%) for group CLP+O $\mathrm{O}_{3}$. Animals of group $\mathrm{CLP}+\mathrm{O}_{2}$ had a survival time that was not significantly different from that of group $\mathrm{CLP}+\mathrm{O}_{3}(71 \mathrm{~h}$ \pm 12.9 vs. $52.1 \pm 8 \mathrm{~h}, p=0.4)$. Animals of group CLP had a mean survival time of $57.4 \pm 10.3 \mathrm{~h}$. The Log-rank test performed between groups CLP, $\mathrm{CLP}+\mathrm{O}_{2}$, and $\mathrm{CLP}+\mathrm{O}_{3}$ showed that there was no statistical difference $(p=0.4)$. These results are illustrated in Figure 4.

\section{DISCUSSION}

The utilization of $\mathrm{O}_{3}$ as a potent antimicrobial agent has been the object of many studies. ${ }^{25-30}$ The use of ozone in humans and animals is still considered controversial because of its side effects that are specifically related to free radical formation and irritation of the respiratory system. ${ }^{12,31}$ For

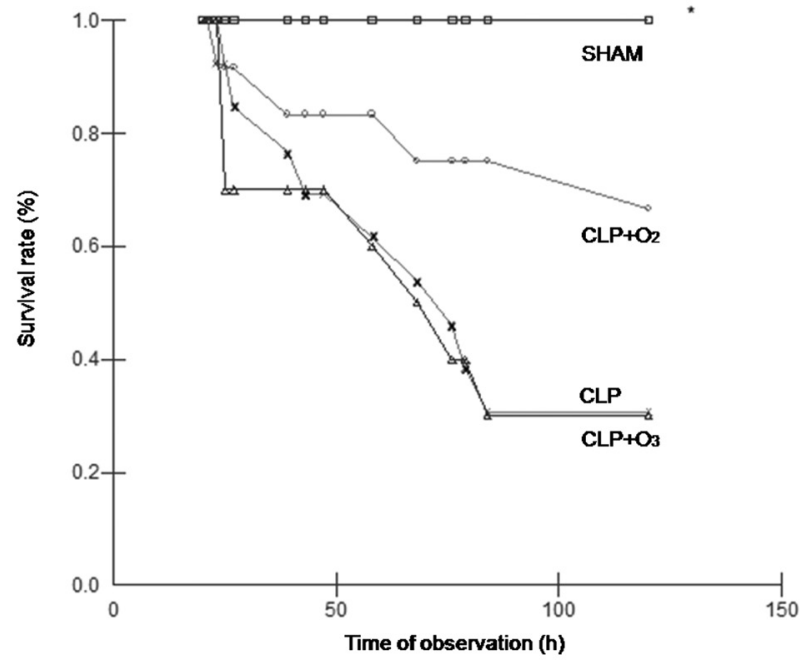

Figure 4 - Log - rank test. The observation period was not completed on only one animal from group SHAM. All of the other groups had a decreased survival time compared to group SHAM $(p=0.002)$. There were no differences in survival among groups CLP, CLP+O ${ }_{2}$, and $\mathrm{CLP}_{3} \mathrm{O}_{3}(p>0.05) . \square=$ SHAM; $\triangle=\mathrm{CLP} ; \mathrm{O}=\mathrm{CLP}^{+\mathrm{O}_{2}} ; \times=\mathrm{CLP}+\mathrm{O}_{3}$.

these reasons, ozone therapy has had limited acceptance in clinical practice, and most of the studies on $\mathrm{O}_{3}$ therapy have been experimental. Despite this fact, ozonized oxygen exhibits various effects on the immune system, such as the modulation of phagocytic activity on the peritoneal ${ }^{32}$ and alveolar ${ }^{33}$ macrophages that generate the first line of defense against bacteria and/or its toxins.

Bette et al. (2006) $)^{13}$ tested a preconditioning $\mathrm{O}_{2} / \mathrm{O}_{3}$ pneumoperitoneum, followed by a tazobactam/piperacilin regimen in Wistar rats submitted to peritonitis, and found an increase in survival rates and a decrease in pro-inflammatory cytokines (TNF- $\alpha$ and IL-1 $\beta$ ). Promisingly, Schulz et al. $(2003)^{14}$ found that after a repetitive pre-treatment using ozonized oxygen (i.p.), mortality in animals submitted to lethal polymicrobial peritonitis was reduced. Rodriguez et al. (2009) ${ }^{1}$ verified that there was an increase of superoxide dismutase (SOD) and glutathione peroxidase (GPx) in rats submitted to ozone oxidative preconditioning (OOP) prior to a fecal peritonitis induction, suggesting that there was a protective effect of OOP. However, in a model of peritoneal sepsis in rats submitted to a 5-day preconditioning period with $\mathrm{O}_{3}$ (i.p), Torossian et al. (2004) ${ }^{15}$ found that survival was reduced from $50 \%$ to $35 \%$ ( $p=0.1$ ). In addition, ozone therapy increased TNF- $\alpha$ and macrophageal inflammatory protein (MIP)-2. From this, the authors concluded that $\mathrm{O}_{3}$ therapy (i.p.) was proinflammatory ${ }^{15}$.

The previous studies with $\mathrm{O}_{3}$ preconditioning ${ }^{1,14,15}$ or preconditioning plus antibiotics ${ }^{13}$ may not have correctly estimated the true impact of ozone therapy in the treatment of septic rats. Therefore, we conducted this study to evaluate the isolated effect of intraperitoneal ozone as a single 
therapeutic agent in intra-abdominal infections.

In this study, the variables were chosen based on the previous reports in the literature ${ }^{1,7,13,14,15,20}$ and for their applicability for the evaluation of SIRS. , $21,24^{2}$

The CLP procedure groups were substantially affected for CINC-1 elevation compared to group SHAM. Group $\mathrm{CLP}+\mathrm{O}_{3}$ had a significant decrease in CINC-1 levels when compared to all of the CLP-procedure groups. CINC-1 plays an important role in the inflammatory response as an attractant and activator of neutrophils and macrophages. ${ }^{34,35}$ However, a previous in vitro study ${ }^{36}$ demonstrated that adhesion and chemotaxis of neutrophils were independent of exposure to ozone when peripheral blood was used. CINC-1 levels rapidly increase after induction of inflammation in rats, especially $8 \mathrm{hrs}$ after the injury ${ }^{35}$, and the levels reach concentrations significantly different from those of controls at 4,8 , and 24 hrs after LPS infusion in blood samples. ${ }^{37}$ The possible mechanism by which CINC-1 expression was modulated in this study remains to be determined. We hypothesize that inactivation of bacteria, as a result of topical (i.p.) application of ozone, could attenuate the migration of macrophages, decreasing CINC-1 expression at $24 \mathrm{~h}$. A histological analysis of the peritoneum after euthanasia by counting the macrophages could provide additional evidence for this hypothesilL- 6 is secreted from T-cells and macrophages and stimulates the immune response to trauma, leading to inflammation. In mice, IL-6 has been shown to be required for resistance against certain species of bacteria, acting as a weak pyrogen. ${ }^{38}$ The CLP procedures increased IL-6 values compared to group SHAM, but groups $\mathrm{CLP}+\mathrm{O}_{3}$ and $\mathrm{CLP}+\mathrm{O}_{2}$ had lower levels of IL-6 than group CLP, and no difference was observed when group $\mathrm{CLP}+\mathrm{O}_{3}$ was compared to group $\mathrm{CLP}+\mathrm{O}_{2}$. Inactivation of bacteria by ozone could explain this decrease in IL-6 levels for group $\mathrm{CLP}+\mathrm{O}_{3}$, but there is no clear mechanism to explain the similar expression of IL- 6 for group $\mathrm{CLP}+\mathrm{O}_{2}$ compared to $\mathrm{CLP}+\mathrm{O}_{3}$.

Intraperitoneal administration of $\mathrm{O}_{2}$ and $\mathrm{O}_{3}$ did not have a significant impact on IL-10 levels after $24 \mathrm{~h}$ of observation. An IL-10 peak can be observed as much as $24 \mathrm{~h}$ after systemic injury. ${ }^{39}$ Anti-inflammatory IL-10 production is known to be part of a protective mechanism that suppresses the induction of proinflammatory cytokines such as TNF- $\alpha$ and IL- 1 and is itself induced by monocytes and macrophages during sepsis..$^{40,41}$ Sewnath et al. $(2001)^{42}$ found a role of endogenous IL-10 in local antibacterial host defense and in the development of SIRS during abdominal sepsis, indicating that endogenous IL-10 increases bacterial clearance.

Previously, it has been shown that an increased histology score is associated with the presence of ALI. ${ }^{43}$ In the CLP groups, the increased histology scores indicate that the CLP procedures provoked pulmonary tissue injury. However, there was no beneficial effect of $\mathrm{O}_{3}$ therapy on the lung histology score. Hyaline membranes were not found in any of the animals, and this compromised the characterization of ALI by histological methods in this study. This might be attributed to the short time interval $(24 \mathrm{~h})$ between the CLP procedures and euthanasia of the animals. Hyaline membranes can be identified by optical microscopy 24 to $48 \mathrm{~h}$ after initial injury. ${ }^{43}$ The presence of edema in the samples that were evaluated $24 \mathrm{~h}$ post-injury was uniformly discreet, and thus we decided to eliminate it in calculating the histology score. The ALI analysis might have been more accurate if pulmonary histology had been performed $48 \mathrm{~h}$ later.

The EBD lung leakage method was chosen because it is an early marker of lung vascular injury. ${ }^{23,24}$ Differences in pulmonary vascular permeability can be observed as soon as $2 \mathrm{~h}$ after procedures such as gut ischemia/reperfusion and lipopolysaccharide (LPS) infusion. ${ }^{23,24}$ Moreover, accumulation of macrophages at sites of tissue injury can be observed after acute inhalation of ozone. ${ }^{44,45}$ These cells, along with resident alveolar epithelial cells, become activated and release cytotoxic and proinflammatory mediators, such as nitric oxide (NO), which increase of pulmonary vascular permeability and to the development of ALI. ${ }^{44,45}$ However, in the present study (with i.p. administration of $\mathrm{O}_{3}$ ), there was a less pronounced capillary permeability (quantified by means of EBD lung leakage) for group $\mathrm{CLP}+\mathrm{O}_{3}$ and this might suggest that $\mathrm{O}_{3}$ therapy had an anti-inflammatory effect. The administration route (i.p.) might have better controlled the intraperitoneal infection ${ }^{7}$ without the undesirable side effects of ozone inhalation. The modulation of the inflammatory cascade might explain the lower EBD lung leakage values for group $\mathrm{CLP}+\mathrm{O}_{3} v s$. groups CLP $+\mathrm{O}_{2}$ and CLP. There was no difference between groups $\mathrm{CLP}+\mathrm{O}_{3}$ and SHAM. This might be due to the small influence that laparotomy and cecal exposure have on pulmonary vascular permeability for group SHAM.

We evaluated the survival rate 5 days after procedure, quantified the survival time in $\mathrm{h}$ for each animal, and performed a Log-rank test. We used a concentration of 102 $\mu \mathrm{g} / \mathrm{ml} \mathrm{O}_{3}$ with a lower volume of the $\mathrm{O}_{2} / \mathrm{O}_{3}$ gas mixture (20 $\mathrm{ml} / \mathrm{kg}$ ). We used a different concentration from that used by Schulz et al..$^{14}(80 \mathrm{~mL} / \mathrm{kg})$ to avoid any potential side effects of massive pneumoperitoneum, but the final concentration of infused ozone was similar. The CLP groups had increased mortality compared to group SHAM ( $p=0.002)$, but no difference was observed when each group was compared to the other $(p=0.12)$. We observed that group CLP had a similar lethality rate (84\%) compared to the classic study 
by Wichterman et al. $(1980)^{20}$ on survival rates after CLP. Thus, in the present study, ozone treatment did not influence survival rates.

In conclusion, the results of our study suggest that intraperitoneal ozone therapy has a possible benefit in attenuating the inflammatory response and acute lung injury resulting from intra-abdominal infection in rats, although there was no improvement in survival rates.

\section{REFERENCES}

1. Rodríguez ZZ, Guanche A, Álvarez RG, Rosales FH, Alonso Y, Schulz $\mathrm{S}$. Preconditioning with ozone/oxygen mixture induces reversion of some indicators of oxidative stress and prevents organic damage in rats with fecal peritonitis. Inflamm Res. 2009;58:371-5.

2. Annane D, Bellisant E, Cavaillon JM. Septic shock. Lancet. 2005;365:63-78.

3. Flowers F, Zimmerman J. Reactive oxygen species in the cellular pathophysiology of shock. New Horiz. 1998;6:169-80.

4. Freitas FG, Salomão R, Tereran N, Mazza BF, Assunção M, Jackiu M, et al. The impact of duration of organ dysfunction on the outcome of patients with severe sepsis and septic shock. Clinics.2008;63:483-8.

5. Rezende E, Silva Junior JM, Isola AM, Campos EV, Amendola CP, Almeida SL. Epidemiology of severe sepsis in the emergency department and difficulties in the initial assistance. Clinics. 2008;63:57-64.

6. Mehlman MA, Borek C. Toxicity and biochemical mechanisms of ozone. Environ Res. 1987; 42:36-53.

7. Silva RA, Garotti JEG, Silva RS, Navarini A, Pacheco Jr A. Analysis of the bactericidal effect of ozone pneumoperitoneum. Acta Cir Bras. 2009;24:124-7.

8. Bocci V, Paulesu L. Studies on the biological effects of ozone: induction of interferon on human leucocytes. Haematologica.1990;75:510-5.

9. Bocci V. Ozone as bioregulator: pharmacology and toxicology of ozonetherapy today. J Biol Regul Homeost Agents. 1996;10:31-53.

10. Buckley RD, Hackney JD, Clark K, Posin C. Ozone and human blood. Arch Environ Health. 1975;30:40-3.

11. Zimran A, Wasser G, Forman L, Gelbart T, Beutler E. Effect of ozone on red blood cell enzymes and intermediates. Acta Haematol. 2000;102:148-51.

12. Bhalla DK, Gupta SK, Reinhart PG. Alteration of epithelial integrity, alkaline phosphatase activity, and fibronectin expression in lungs of rats exposed to ozone. J Toxicol Environ Health A. 1999;57:329-43.

13. Bette M, Nuesing RM, Mutters R, Menendez S, Schulz S. Efficiency of tazobactam/piperacilin in lethal peritonitis is enhanced after preconditioning of rats with $\mathrm{O}_{3} / \mathrm{O}_{2}$ pneumoperitoneum. Shock. 2006;1:26-9.

14. Schulz S, Rodriguez ZZ, Mutters R, Menendez S, Bette M. Repetitive pneumoperitoneum with ozonized oxygen as a preventive in lethal polymicrobial sepsis in rats. Eur Surg Res. 2003;35:26-34.

15. Torossian A, Ruehlmann S, Eberhart L, Middeke M, Wulf H, Bauhofer A. Pre-treatment with ozonized oxygen $\left(\mathrm{O}_{3}\right)$ aggravates inflammation in septic rats. Inflamm Res. 2004;53:S122-5.
16. Institute of Laboratory Animals Resources. Guide for the Care and Use of Laboratory Animals. Washington, DC, USA: National Academy Press, 1996.

17. Arruda MJC de, Poggetti RS, Fontes B, Lima WT de, Trezena $\mathrm{AG}$, Birolini D. Intestinal ischemia/reperfusion induces bronchial hyperreactivity and increases serum TNF-alpha in rats.. Clinics. 2006;61:21-8.

18. Nakagawa, NK, Jukemura J, Aikawa P, Nogueira RA, Poli-de-Figueredo IF, Sannomiya P. In vivo observation of mesenteric leukocyte-endothelial interactions after cecal ligation/puncture and surgical sepsis source control. Clinics. 2007;62:321-6.

19. Lee DK, Terrazas RG, Votto LG, Arenson-Pandikow H. Techniques of inhalatory induction in rats: a comparative study. Acta Cir Bras.1994;9:34-7

20. Wichterman, KA, Baue AE, Chaudry IH. Sepsis and septic shock-a review of laboratory models and a proposal. J Surg Res. 1980;29:189201.

21. Martins JO, Zanoni FL, Martins DO, Coimbra R, Krieger JE, Jancar S, et al. Insulin regulates cytokines and intercellular adhesion molecule-1 gene expression through nf-kb activation in lipopolysaccaride-induced acute lung injury in rats. Shock. 2009;31:404-9.

22. Capelozzi VL, Saldiva PH, Antonângelo L, de Carvalho TS, Logulo A, de Carvalho CR, et al. Quantitation in inflammatory pleural disease to distinguish tuberculous and paramalignant from chronic non-specific pleuritis. J Clin Pathol.1997;50:935-40.

23. Dallal MM, Chang SW. Evans blue dye in the assessment of permeability surface area product in perfused rat lungs. J Appl Physiol. 1994;77:10305 .

24. Moraes LB, Murakami AH, Fontes B, Poggetti RS, Van Roojen N, Younes RN, Heimbecker AM, Birolini D. Gut ischemia/reperfusion induced acute lung injury is an alveolar macrophage dependent event. J Trauma Inj Inf Crit Care. 2008; 64:1196-200.

25. Roy D, Wong PK, Engelbrecht RS, Chian ES. Mechanism of enteroviral inactivation by ozone. Appl Environ Microbiol. 1981;41:718-23.

26. Dyas A, Boughton BJ, Das BC. Ozone killing action against bacterial and fungal species:microbiological testing of a domestic ozone generator. J Clin Pathol. 1983;36:1102-4.

27. Olson WP. Ozone. PDA J Pharm Sci Technol. 1999;53:125-8.

28. Steinhart H, Schulz S, Mutters R. Evaluation of ozonated oxygen in an experimental animal model of osteomyelitis as a further treatment option for skull-base osteomyelitis. Eur Arch Otorhinolaryngol.1999;256:153-7.

29. Sechi LA, Lezcano I, Nunez N, Espim M, Dupre I, Pinna A, et al. Antibacterial activity of ozonized sunflower oil(oleozon). J Appl Microbiol. 2001;90:279-84. 
30. Fan L, Song J, McRae KB, Walker BA, Sharpe D. Gaseous ozone treatment inactivates Listeria innocua in vitro. J Appl Microbio.2007;103:2657-63.

31. Pryor, WA. Mechanisms of radical formation from reactions of ozone with target molecules in the lung. Free Radic Biol Med. 1994;17:451-65.

32. Canning BJ, Hmieleski RR, Spannhake EW, Jakab GJ. Ozone reduces murine alveolar and peritoneal macrophage phagocytosis: the role of prostanoids. Am J Physiol. 1991;261:L277-82.

33. Chatterjee D, Mukherjee SK. Destruction of phagocytosis-supressing activity of aflatoxin B1 by ozone. Lett Appl Microbiol. 1993;17:52-4.

34. Shibata F, Kato H, Konishi K, Okumura A, Ochiai H, Katsuhisa N, et al. Differential changes in the concentrations of cytokine -induced neutrophil chemoattractant (CINC)-1 and CINC-2 in exudate during rat lipolysccharide-induced inflammation. Cytokine. 1996;8:222-6.

35. Kunkel SL, Lukacs NW, Strieter RM. The role of interleukin-8 in the infectious process. Ann N Y Acad Sci.1994;730:134-43.

36. Margalit M, Attias E, Attias D, Elstein D, Zimran A, Matzner Y. Effect of ozone on neutrophil function in vitro. Clin Lab Haematol.2002; 23:243-7.

37. Focà A, Berlinghieri MC, Barreca GS, Placanica PM, Diana R, Liberto MC, et al. Kinetics of IL-8, MIP-1 alpha, TNF alpha, IL-1 beta, IL-1ra and IL-10 in human whole blood samples triggered by smooth and rough LPS. New Microbiol. 1998;21:123-30.

38. Nilsberth C, Elander L, Hamzic N, Norell M, Lönn J, Engström L, et al. The role of interleukin-6 in lipopolysaccharide-induced fever by mechanisms independent of prostaglandin E2. Endocrinology.2009;150:1850-60.
39. Seghaye MC, Duchateau J, Bruniaux J, Demontoux S, Bosson C, Serraf A, et al. Interleukin-10 release related to cardiopulmonary bypass in infants undergoing cardiac operations. J Thorac Cardiovasc Surg. 1996;111:545-53.

40. Kato T, Murata A, Ishida H, Toda H, Tanaka N, Hayashida H, et al. Interleukin 10 reduces mortality from severe peritonitis in mice. Antimicrob Agents Chemother. 1995;39:1336-40.

41. van der Poll T, Marchant A, Buurman WA, Berman L, Keogh CV, Lazarus DD, et al. Endogenous IL-10 protects mice from death during septic peritonitis. J Immunol. 1995; 155:5397-401.

42. Sewnath ME, Olszyna DP, Birjmohun R, ten Kate FJ, Gouma DJ, van Der Poll T. IL-10-deficient mice demonstrate multiple organ failure and increased mortality during Escherichia coli peritonitis despite an accelerated bacterial clearance. J Immunol. 2001;166:6323-31.

43. Menezes SLS, Bozza PT, Faria Neto HCC, Laranjeira AP, Negri EM, Capelozzi VL, et al. Pulmonary and extrapulmonary acute lung injury: inflammatory and ultrastructural analyses J Appl Physiol. 2005;98:177783.

44. Laskin DL, Sunil V, Guo Y, Heck DE, Laskin JD. Increased Nitric Oxide Synthase in the Lung after Ozone Inhalation Is Associated with Activation of NF-кB. Environ Health Perspect Suppl.1998;106(S5):1175-9.

45. Cerqueira NF, Yoshida WB. Óxido nítrico: revisão Cerqueira NF, Yoshida WB. Óxido nítrico: Revisão. 2002. Acta Cir Bras;17:417-23. 